\title{
Case study of negative impact of concave coal basin on long ribbon building development
}

\author{
Beata Parkasiewicz, ${ }^{*}$, and Marian Kawulok \\ Building Research Institute (ITB), Filtrowa 1 00-611 Warsaw, Poland
}

\begin{abstract}
The development analysed in this article was under the effects of mining activity in 2012-2016, most importantly in the area of influence of the mining basin. As a result of the mining activity, the terrain became considerably deformed and sloped. Effects on the buildings' condition consisted in tilt of the segments, measuring between $10-25 \mathrm{~mm} / \mathrm{m}$. The units also moved in relation to each other at the movement joints, and their structure suffered heavy damage, mostly in the form of cracks and chips on the walls.

For ribbon buildings, i.e. buildings which may be divided with movement joints and which may form long rows, specific locations on top of a mining basin may lead to endangering the safety of structures and their users, even in newly constructed buildings.
\end{abstract}

\section{Introduction}

Coal mining is a crucial part of Polish energy-related economy. This fossil fuel is the most important source of electrical power in the country.

However, underground coal mining, despite all its economic advantages, generates negative consequences on the surface, which we refer to as 'mining damage'. According to [1] it is defined as 'all adverse effects caused by mining to the natural environment and land development features (...)'. Underground mining forces affect the natural landscape, causing continuous or non-continuous deformations or vibrations of subsoil under buildings.

Effects consisting of continuous deformation and characterized using basin parameters (fig. 1), are among the most common.

\footnotetext{
*Corresponding author: b.parkasiewicz@itb.plbparkasiewicz@mail.com
} 


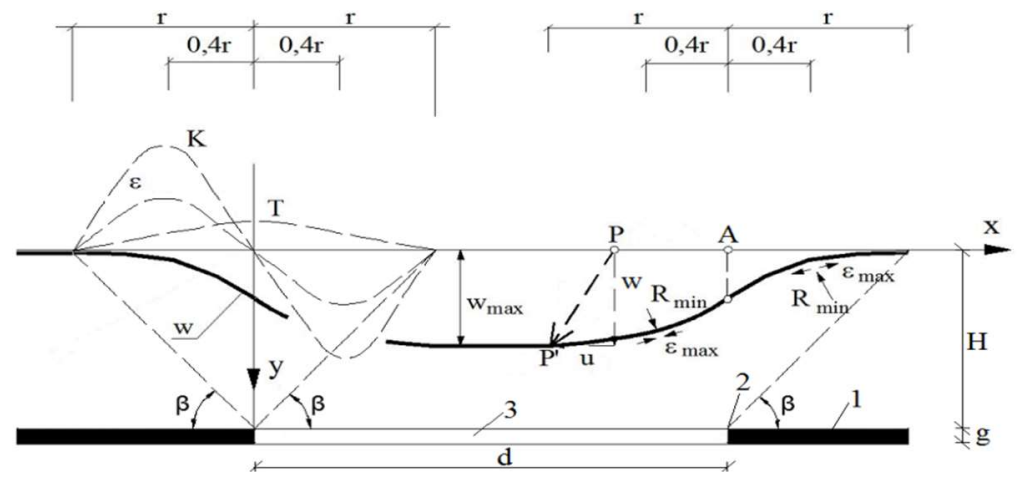

Fig. 1. Basin of mining area $(\mathrm{H}-$ depth of exploitation, $\mathrm{g}-$ deck thickness, $\mathrm{r}$ - radius of major influences, $\mathrm{d}$ - width of selected deck, $\mathrm{w}-$ vertical displacement (reduction) of terrain, $\mathrm{u}$ - horizontal displacement, $\mathrm{T}$ - ground slope, $\mathrm{K}$ - curvature, curvature radius $\mathrm{R}=1 / \mathrm{K}, \varepsilon$ - horizontal deformation , $\beta$-influences angle, 1 - carbon board, 2 - front mining exploitation, 3 - selected coal deck). Source

Mining damage is mostly assigned to older buildings, ones often having a high degree of natural wear. The case presented in the article shows that negative influence of mining may also affect newly constructed buildings.

Design and construction of buildings in mining areas is often tied to multiple problems. Before starting a project, the owner has the obligation to obtain information from the mining company regarding the designed influences. The mining company states the influences which may appear, but only within the concession period and on the day of issuing the statement. Predictions included in the document are usually limited to terrain deformation category. Therefore, they do not account for location of specific mining parcels in relation to the designed buildings. This does not, however, remove the designer's duty to analyse the worst case scenarios [3].

The case has been subjected to Polish publications, where the effects of mining influence in 2010-2014 on row b was presented [4] and in 2014-2016 on row a [5]. In [6] presented in this article example, was presented only in general terms.

\section{Development description}

The analysed development was built in 2012 and 2013, using the traditional construction method, with two-storey superstructure, non-residential attic and without a basement.

The houses form long rows which have a length of $50 \mathrm{~m}$ to $70 \mathrm{~m}$ and consist of either four or five segments (fig. 2). Each segment is $7.2 \mathrm{~m}$ to $14.1 \mathrm{~m}$ long with a width of $10.5 \mathrm{~m}$ or $11.1 \mathrm{~m}$. Architecturally, the segments are one of two types (type A: rows a and b-fig. 2, type B: rows $\mathrm{c}$ and $\mathrm{d}-\mathrm{fig}$. 3). These types differ in roof structure, the shape of the attic and slightly in the plan dimensions. 


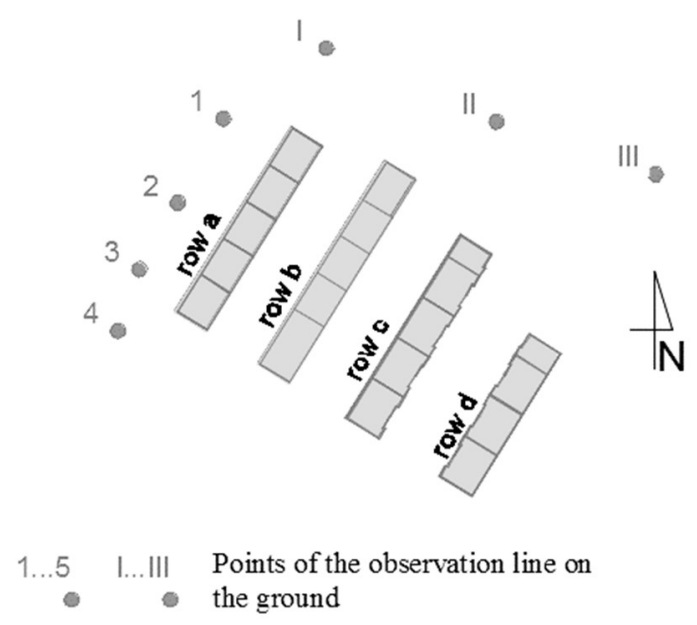

Fig. 2. The location of the newly built development with the mining situation. Performed on the basis of [5].

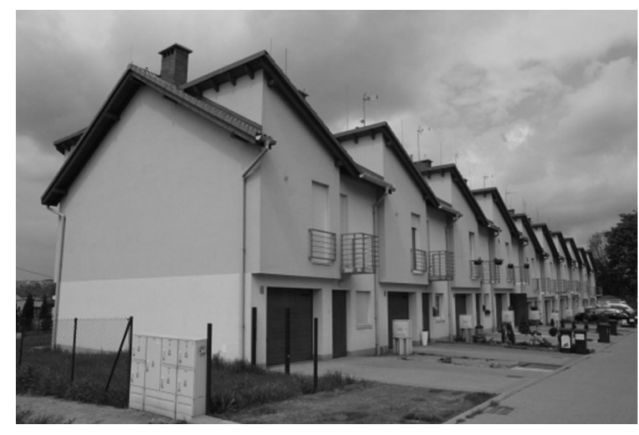

Fig.3. A view on a ribbon building of type A. Performed by L. Chomacki.

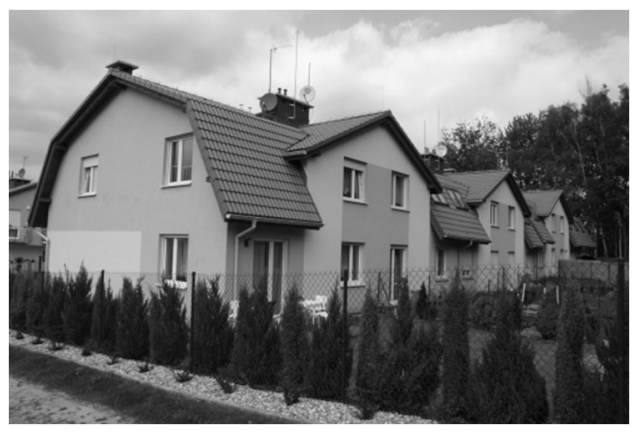

Fig.4. A view on a ribbon building of type B. Performed by L. Chomacki.

The main elements transferring the loads from the roof and floors to the foundations are the transverse reinforced concrete walls and the longitudinal reinforced concrete wall, which mostly has a stiffening function. The segments are supported by a set of in-situ reinforced concrete strip foundations with ties. Curtain walls are made of ceramic, hollow bricks and insulated with expanded polystyrene. Corners and intersections of the masonry walls include reinforced cores anchored to the foundations. The floors are mostly precast 'filigran' slabs. Tie beams, lintels, slabs and indoor stairs use prefabricated concrete. The roof structure is wooden and is either a purlin and rafter roof (type A) or a mansard roof (type B). Roof coating is made of ceramic tiles.

Movement joints were designed between segments with a width of $10 \mathrm{~cm}$. During the construction, due to practical issues, the movement joints were completely filled with expanded polystyrene. Additionally, no joint was constructed in the roof.

Moreover, the design mentions that the development was designed to transfer forces corresponding to category III deformations. That means, the $\mid$ Designer should made the calculation using follow parameters: $\varepsilon_{\mathrm{k}}=6,0 \mathrm{~mm} / \mathrm{m}$, calculation factor $\gamma_{\mathrm{f}}=1,3$ and $\mathrm{R}_{\mathrm{k}}=6,0 \mathrm{~km}$ $\gamma_{\mathrm{f}}=1,7$ [3]. 


\section{Mining conditions and surveying measurements of the area}

In the vicinity of the analysed development, intense mining of two deposits was carried out between 2010 and 2016 (fig. 5):

- exploitation 1: in the first deposit, with two walls, each with a height of $2.0 \mathrm{~m}$ (wall 1 at an average depth of c. $610 \mathrm{~m}$ between 05.2010 and 06.2013 and wall 2 at an average depth of 660 between 07.2013 and 03.2014 ),

- exploitation 2: in the second deposit, with two walls, each with a height of $2.2 \mathrm{~m}$ (wall 3 at an average depth of c. $680 \mathrm{~m}$ in 01.2015 to 05.2015 and wall 4 at an average depth of 660 in 10.2015 to 07.2016 ).

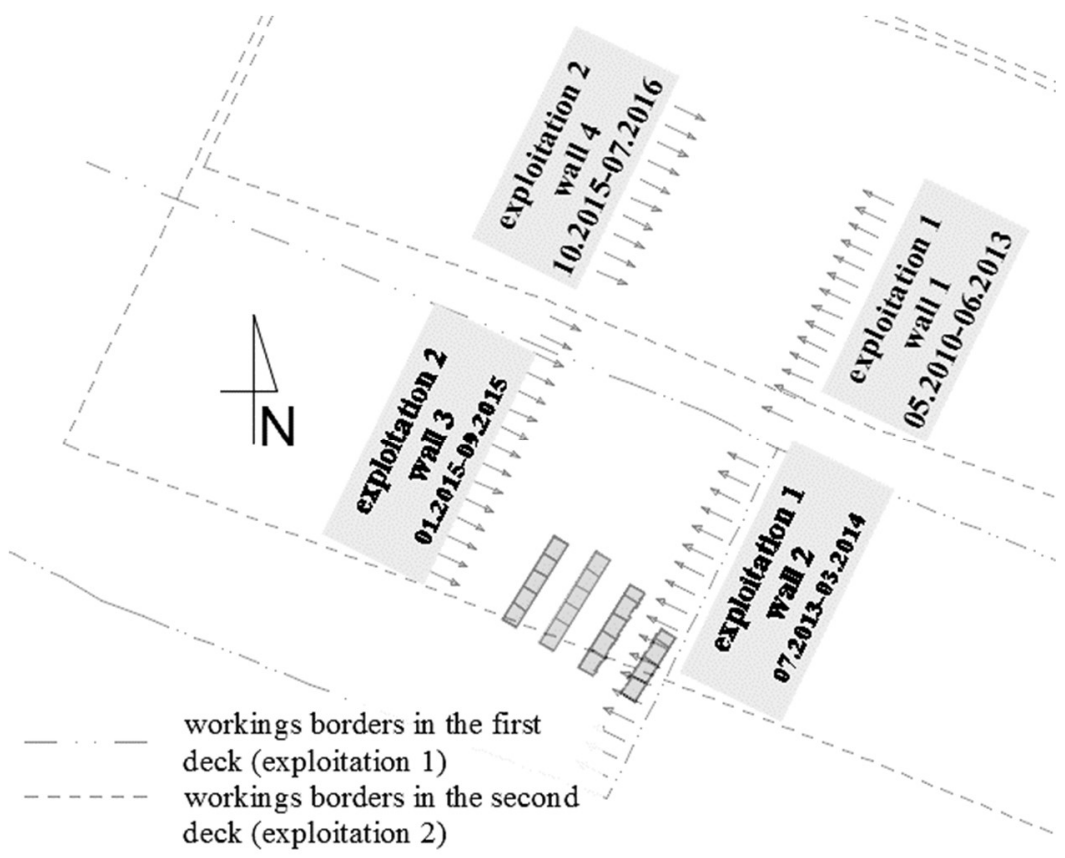

Fig. 5.The Mining situation in the area of discussed buildings. Performed on the basis of [5].

The designer received information from the mining company that in 2011-2020 the designed building development will be located in the influence zone of category III deformations, i.e. according to $[3,7]$ characteristic parameters may reach the following boundary values:

- horizontal soil deformation: $\varepsilon=6 \mathrm{~mm} / \mathrm{m}$,

- radius of curvature of the terrain: $\mathrm{R}=6 \mathrm{~km}$,

- soil tilt: $\mathrm{T}=10 \mathrm{~mm} / \mathrm{m}$.

The values above have to be used while designing a building development.

Surveying measurements were taken in 2011-2016 in the areas adjacent to the development, at certain observation points (fig. 2).

Measurements of vertical depression were taken in points 1, 3 and 5 between 05.2011 and 03.2016, and in points I-III between 04.2011 and 03.2016. In points 2 and 4 the measurements of depression were only taken since 2013 , which is why these results will not be considered in the analysis further on. The measured vertical depression allowed to calculate the terrain's tilt in sections $1-3,3-5$. Horizontal deformation of the soil between specific points on the first line of measurement was measured between 07.2013 and 03.2016. 
Fig. 6-9 shows the measured values. The figures show duration of particular exploitation periods.

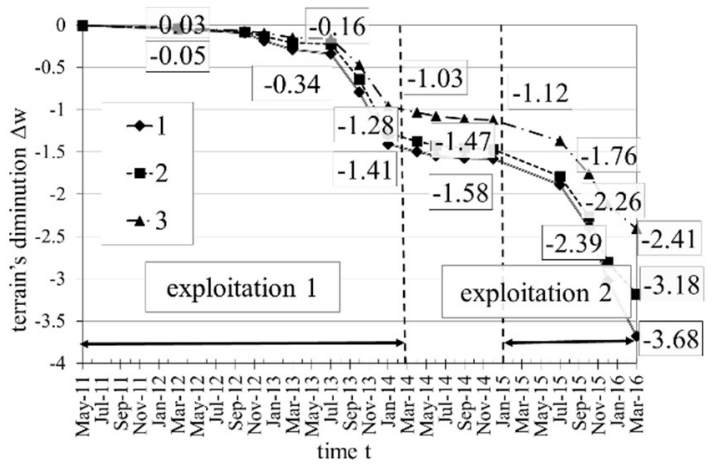

Fig. 6. Increase of terrain's diminution in time from 05.2011 to 03.2016 in sections 1,3 and 5. Made on the basis of [5].

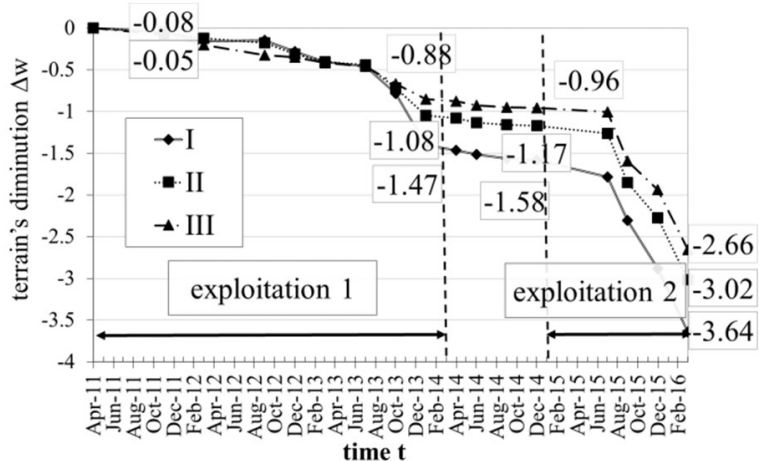

Fig. 7. Increase of terrain's diminution in time from 04.2011 to 03.2016 in sections I to III. Made on the basis of [5].

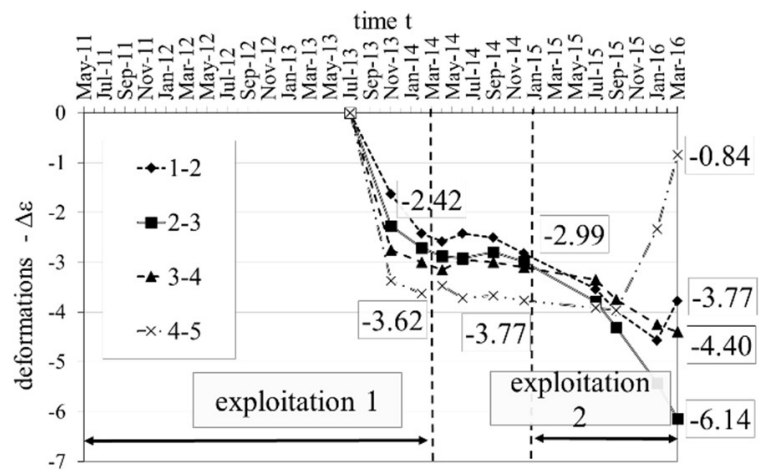

Fig. 8. Deformations between sections in time from 07.2013 to 03.2016 - measuring line $1-5$. Made on the basis of [5]. 


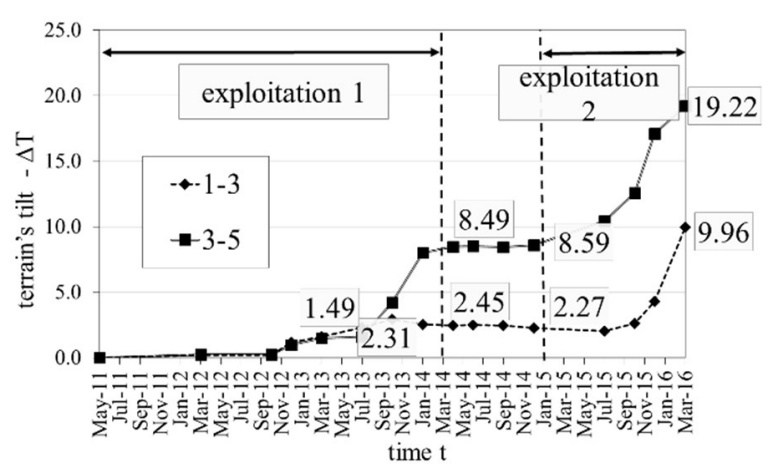

Fig. 9. Increase of terrain's tilt in time from 05.2011 to 03.2016 in sections 1,3 and 5. Made on the basis of [5].

The mining activity covering the analysed building development resulted in a considerable deformation of the soil, which can be described with the following parameters: - maximum terrain depression equal to $-3.68 \mathrm{~m}$ (point 1, fig. 6),

- maximum terrain deformation equal to $-6.14 \mathrm{~mm} / \mathrm{m}$ (section $2-3$, fig. 8), - maximum terrain tilt equal to $19.22 \mathrm{~mm} / \mathrm{m}$ (section 3-5, fig 9).

The information quoted above shows that the values of predicted category III influences indicated in the mining and geological statement have been exceeded considerably, especially the terrain tilt.

At the same time, due to lack of full measurements of the horizontal deformation of the terrain (fig. 8) we must assume that earlier mining activity had no influence on the building's condition. Analysing the position of the mining plain, the authors have decided that the measurements were likely initiated after major influences on the buildings became visible on the ground surface.

\section{Condition of the buildings}

The buildings in question were subject to changes which contributed to deterioration of their technical condition, during both 1 st and 2nd mining operations. They incurred heavy damage, and segments tilted heavily and moved in relation to one another. In particular, after the 2 nd mining operation, a technical condition developed which posed danger to the structure and its users.

Particular segments of each rows were tilted, mostly towards the north-west direction, and the value of the tilt exceeded $10 \mathrm{~mm} / \mathrm{m}$ in the majority of cases. A regularity could be observed that in each of the rows, the greatest tilt was recorded in the end segments, with a value of up to $25 \mathrm{~mm} / \mathrm{m}$ (row a, segment 1). The measurements taken by the owner in 2016 [7], show that the tilt was equal to:

- in row a - from $11 \mathrm{~mm} / \mathrm{m}$ up to $25 \mathrm{~mm} / \mathrm{m}$,

- in row b - from $10 \mathrm{~mm} / \mathrm{m}$ up to $24 \mathrm{~mm} / \mathrm{m}$,

- in row c - from $11 \mathrm{~mm} / \mathrm{m}$ up to $20 \mathrm{~mm} / \mathrm{m}$,

- in row $\mathrm{d}$ - from $15 \mathrm{~mm} / \mathrm{m}$ up to $18 \mathrm{~mm} / \mathrm{m}$,

The development suffered damage to nearly all of its buildings. The most severe damage was documented in A type rows ( $a$ and $b$ ). 
The damage can be classified both as structural damage and secondary damage, i.e. [4]:

a) group I - mostly structural damage (row a-c):

- damage to longitudinal curtain walls, stiffening walls, division walls in the form of diagonal cracks and chips; the width of these cracks was up to $1 \mathrm{~cm}$ on first floor level (fig. 10-12),

- cracks and chips of transverse load bearing walls with a width of up to $1 \mathrm{~cm}$,

- damage to transverse division walls in the form of diagonal and horizontal cracks and chips with a width of up to $8 \mathrm{~mm}$ (fig. 13),

- occasional damage (cracks) to floor slabs recorded in segment 1 on ground floor,

- damage to chimneys - cracks and chips, mainly on attic level,

b) group II - damage around movement joints (entire development):

- cracks coupled with convex deformation of the walls adjacent to the joints, at half height, horizontal, occasionally slightly diagonal, up to c. $1 \mathrm{~mm}$ wide; this damage had already been present before, as described in [4] (fig. 14),

- damage to façades, caused by displacement of the segments apparent at the joints,

c) group III - irregularities at roof level in the form of displacement of roof structure elements and cracks of secondary elements (row a-c),

d) group IV - damage of technological nature, i.e. damage at the connections of walls and floors, as well as structural elements of different materials (entire development),

e) group $\mathrm{V}$ - damage to drywall, mostly in the attic, in the form of cracks and chips (row $\mathrm{a}-\mathrm{c})$,

f) group VI - other damage, such as displacement of road brick towards the inside of the building (row a and b).

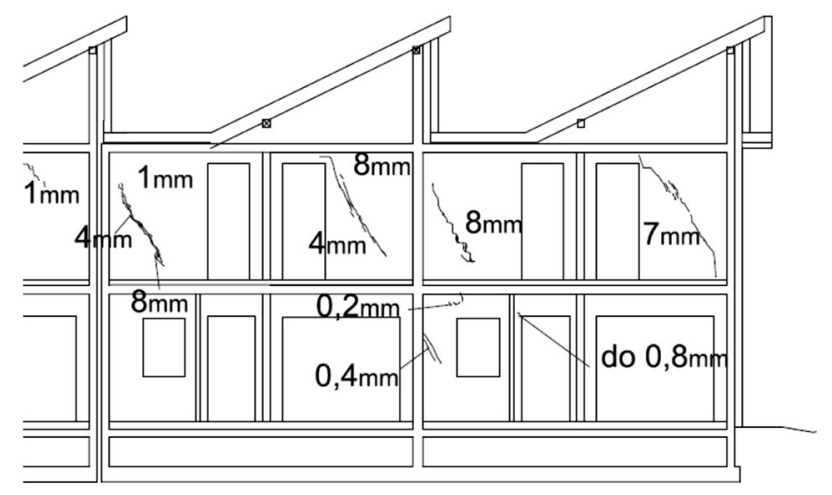

Fig. 10. Damage to external longitudinal curtain walls in the example of an extreme southern segment of the row a. Source [5]. 


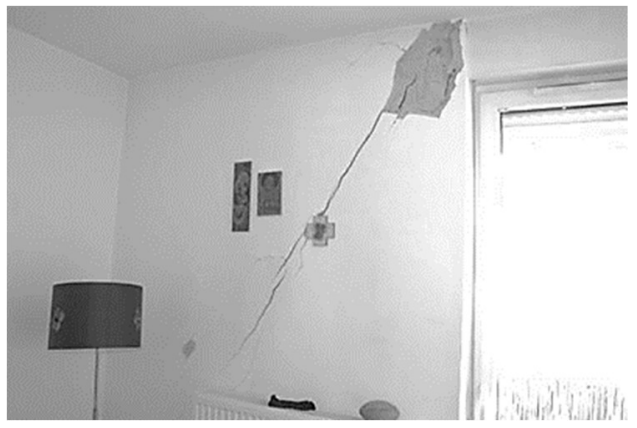

Fig. 11. Cracks in the east outer cover wall on the 1 st floor in the first segment in the row b. Source [5].
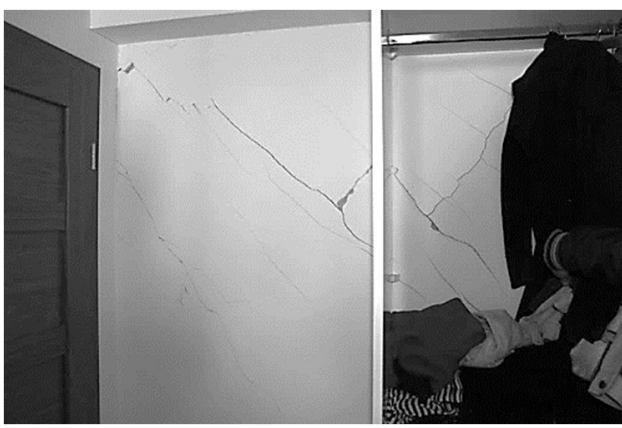

Fig. 13. Cracks in the longitudinal wall of the staircase on the 1st floor in the row b. Source [5].

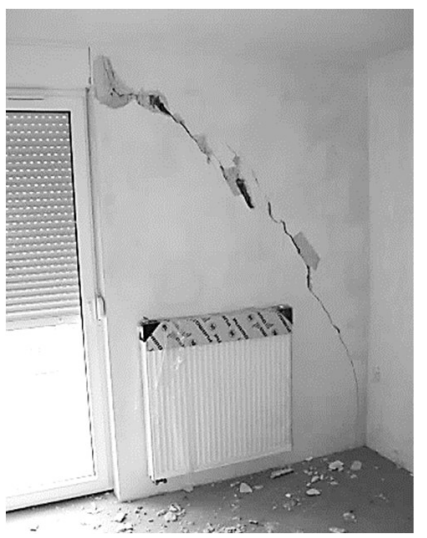

Fig. 12. Cracks in the east outer cover wall on the 1st floor in the first segment in the row a. Source [4].

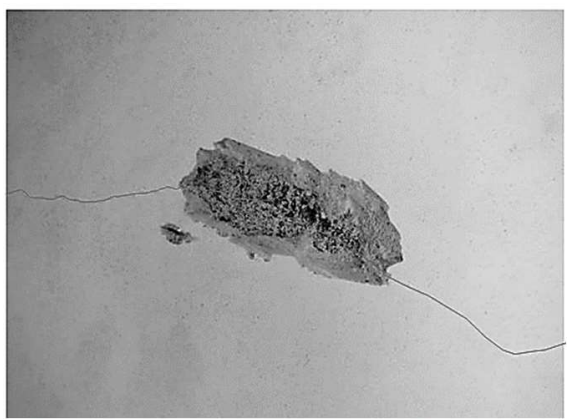

Fig. 14. Scratch a wall Transverse at dilatation On the 1st floor in the row a. Source [5].

\section{Influence of mining on the buildings and cause of damage}

The current condition of the complex, as shown by analysis in [4], was caused by the influence originating in mining in deposits 1 and 2, aggravated by the incorrectly built movement joints.

Due to the mining activity, the analysed buildings were nearly continuously within range of influence of the mining basin in 2012-2016. As a result of the mining situation segments were tilted and displaced in relation to one another in the joints. Furthermore certain construction elements suffered serious mechanical damage.

The segment tilt was from $10 \mathrm{~mm} / \mathrm{m}$ to $25 \mathrm{~mm} / \mathrm{m}$ in the north-west direction; it can be said that it was caused by the terrain sloping [4]. Such a tilt, according to [6], diminishes the buildings' serviceability. In this case we were dealing with inconvenience: minor - in seven segments, moderate - in ten segments and major - in two segments.

The influence of horizontal compressive strains may have caused segments to get closer to one another at the joints along the entire height. Moreover, due to differences in tilt of different segments theoretically some additional displacement may have occurred at the top of the segments. To sum up, the relative displacement of the segments at the top was caused 
both by displacement resulting from compressive strains in the soil and differences in tilt of particular segments.

In practice however, due to overly narrow and partly obstructed movement joints, the displacement could not take place, which led to damage being incurred by the buildings' structure (group I damage). At the same time it should be pointed out that the width of the joint was slightly smaller than required for category III (it should be $12.5 \mathrm{~cm}$, but was only $10 \mathrm{~cm}$ ). In addition, the joint was completely filled with expanded polystyrene shits (EPS). The influences that were present in reality would require the joint to be as wide as $17 \mathrm{~cm}$ $[5]$.

Group II damage appeared during exploitation of deposit 1 [4]. Based on analyses carried out in 2014 it was determined that the damage may have occurred as a result of additional pressure exerted on the transverse load bearing walls and the layers of compressed EPS in the movement joints. Using the EPS was not correct. This situation may have led to convex deformation and horizontal cracks with a slight diagonal slope on the walls.

The reason given for group III damage was lack of movement joint in the roof and between the roof surface and the walls. The roof surface of the entire row performed as one plate, and with additional horizontal displacement caused by the mining activity, structural elements of the roof moved and pulled other elements, which resulted in damage.

Group IV encompasses damage resulting from the construction technology used for building elements. It cannot be ruled out that this damage was exacerbated by the mining activity influence.

Group V damage, affecting drywall, is a common type of damage, which may occur during normal usage of buildings and is not exclusive to mining areas. At the same time, similarly to the previous group, cracks may have been widened by the effects of mining activity.

\section{Summary}

The article discusses the case of a residential development in a specific location in relation to mining work. With this mining activity, influences from mining exploitation 1 and 2 have accumulated Major ground sloping has occurred as well as horizontal compressive strains. As a consequence, the segments of the buildings separated with movement joints tilted and were displaced in relation to one another in the movement joints and the structure elements were significantly damaged.

The condition of the development was the result on the one hand of strong mining influences the parameters of which exceed those corresponding to the expected category III, and on the other - of incorrect adjustment of the joint spaces or missing joints in the roof.

The effects of the mining activity described in this article would have been much less severe for detached houses.

For longer ribbon buildings, correct structure of movement joints is crucial [3]. They need to have the ability to transfer mining influences along their full height. At the same time they should not be filled with any materials, in order to allow the units to move. It should also be pointed out that influences originating from different, subsequent mining operations may accumulate (fig. 15).

In the case of the buildings being analysed, in order to restore structural safety and safety of usage repairs need to be undertaken which will return them to their original state. Damaged construction elements should be erected anew. Tilted units should be straightened by levelling floors and walls, which may prove to be a very complicated exploitation, or by using hydraulic actuators. In the event of another mining operation, the movement joints 
should be adjusted to allow them to transfer the influences, in accordance with recommendations given above.

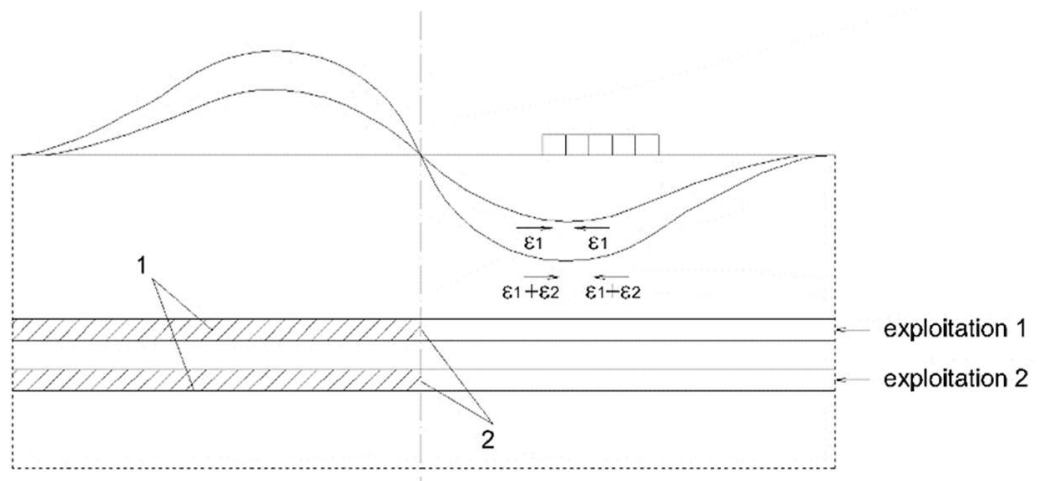

Fig. 15. Effects on the row building from two exploitations. Designations: $1-$ carbon board, $2-$ operating front, $\varepsilon_{1}$ - influence from exploitation $1, \varepsilon_{1}+\varepsilon_{2}$ - Total influences from exploitation 1 and exploitation 2. Source [6]

\section{References}

1. M. Kawulok, Szkodygórnicze $w$ budownictwie (Mining damage in construction) (Building Research Institute ITB, Warsaw, 2010)

2. W. Borecki, Chudek M., Mechanika górotworu(Rock mechanics)(Publisher Śląsk, Katowice, 1972)

3. Instrukcjanr 416/2006: Projektowaniebudynkównaterenachgórniczych (Instruction no 416/2006: Design of buildings in mining areas) (Building Research Institute ITB, Warsaw, 2006)

4. M. Kawulok, B. Parkasiewicz, Skutki eksploatacji górniczej w szeregowej zabudowie mieszkalnej (The effects of mining exploitation in the residential ribbon building) $35 \div 46$ (AGH, Krakow, 2016)

5. B. Parkasiewicz, L. Chomacki, M. Kawulok, Uszkodzenia nowo wybudowanej szeregowej zabudowy mieszkalnej spowodowane oddziaływaniem wklęstej niecki terenu górniczego (Damage in newly built ribbon building development due to effect of concave basin of mining area), Mining Review (to be published)

6. B. Parkasiewicz, L. Chomacki, L. Słowik, Negatywny wpływ odkształceń poziomych o charakterze ściskań (-ع) na budynki $i$ zastosowany zakres interwencji (The negative impact of compressive horizontal distortions (-E) on buildings and the scope of intervention applied) $253 \div 270$ (PZITB, Katowice, 2016)

7. Instrukcjanr 12: Zasadyocenymożliwościprowadzeniapodziemnejeksploatacjigórniczej $z$ uwaginaochronęobiektówbudowlanych (Instruction No 12: Principles for the assessment of underground mining exploitation possibilities in view of the protection of construction works) (Central Mining Institute GIG, Katowice, 2000)

8. Measuring the difference of floor heights in segments and measurement of the corner inclination of the series, (Katowice, 2016). Material provided by the investor 